comment; and they will have served their purpose if they direct attention to the part played in the phenomena of terrestrial magnetism by moving conductors. It will be noticed that they leave untouched the mysterious and important connection between sun spots and magnetic disturbances.

B. STEWART

P.S.-Since writing the above, Prof. Sir W. Thomson has informed me that Faraday tried to detect induction currents by tides in the Thames, but found no positive result. In an article in the Philosophical Magazine, Dec. I85 I, Prof. Sir W. Thomson quotes this idea of Faraday, and makes a proposal to test it from tides in the Channel. $\mathrm{He}$ also discusses the part which may be played in the phenomena of terrestrial magnetism by moving conductors.

\section{BRITISH RAINFALL}

MR. G. J. SYMONS (62, Camden Square, N.W., 1 December 22, 1869) sends us the following list of localities whence observations are "urgently required;" we think he will have many volunteers:-Cornwall : Falmouth, Jacobstow. Devon: Hatherleigh, Hartland, Exmoor. Dorset: Bere Regis. Oxford: Thame. Surrey: Redhill. Suffolk: Halesworth, Mildenhall. Lincoln: Kirton. Nottingham : Mansfield. Warwick: Stratfordupon-Avon. Shropshire: Bishop's Castle. Yorkshire : Milford Junction, Pateley Bridge, Kettlewell, Askrigg, Driffield, Bridlington, on the North York Moors. Lancashire: Broughton. Northumberland: Haltwhistle. Cumberland: Kirkoswald. Westmoreland: Ravenstonedale. Isle of Man: any part of the Island. Pembroke: Tenby, Fishguard. Cardigan: Aberaeron, Brecknock, Llanwrtyd. Radnor : Builth, Knighton. Montgomery: Montgomery, Ilanfyllin. Merioneth: Barmouth, Harlech. Carnarvon: Pentrevoclas. Wigtown: Northern part of. Kirkcudbright: Western part of. Peebles: Peebles, Biggar. Ayr : Muirkirk. Argyle: Mull of Cantire, Ballimore, Glencoe, near Ben Cruachan. Perth: North-west part of. Forfar: Western part of. Inverness: along the Caledonian Canal, and in Lochaber. Aberdeen : North-west part of. Nairn: any part of. Banff : Southern part of. Ross: any place inland, or in Lewis or Harris. Sutherland: any place inland. Caithness: any place inland. Ireland: except from the vicinity of Belfast, Dublin, Londonderry, and Waterford, where there are many observers, returns are required from nearly all parts of the country.

\section{THE LATE PROFESSOR MICHAEL SARS, OF CHRISTIANIA}

PHIS eminent zoologist died on the 22nd of October last; and his loss will be much felt by all naturalists who have benefited, as I have done, by his long, laborious, and conscientious investigation of the invertebrate fauna of the Norwegian seas.

He was born on the 3oth of August, I 805, at Bergen, where his father was a shipowner. After finishing his icademical studies at Christiania, and evincing at an carly age his predilection for natural science, he entered into priest's orders, and in 1830 became pastor at Kinn, in the diocese of Bergen. Ten years afterwards he had charge of the parish of Manger in the same diocese. As both these parishes were on the sea-coast, Sars had constant opportunities of pursuing his zoological researches. In 1829 he published his first essay, entitled "Bidrag til Söedyrenes Natur-historie;" and in I 846 the first part of his celebrated work "Fauna littoralis Norvegiæ." In J 854 he was appointed Professor Extraordinarius of Zoology at the University of Christiania, a position which he filled up to the time of his lamented death with great horiour to his country, and to the satisfaction of the whole world of science. His celebrity as a zoologist, as well as a palæontologist, was fully recognised by all naturalists and geologists, and he was elected a member of several foreign scientific societies. Our own distinguished countryman, the late Edward Forbes, individually showed his appreciation of Sars's labours in eloquent pages $(66$ and 67) of his own posthumous work, "The Natural History of the European Seas," when he said, "More complete or more valuable zoological researches than those of Sars have rarely been contributed to the science of Natural History, and the success with which he has prosecuted investigations claiming not only a high systematic value, but also a. deep physiological import, is a wonderful evidence of the abundance of intellectual resources which genius can develop, however secluded and wherever its lot be cast;" and he added that the name of this Norwegian priest, "who reaped reputation when seeking no more than knowledge familiar to every naturalist in Europe and America, in Asia, and at the Antipodes - for there are great naturalists settled far. in the south, and many in the far east-is a sufficient proof that able work brings the rewards of applause and veneration, even when they be unasked for." By the observations of Sars on the development of the Medusæ he greatly advanced our knowledge of that remarkable physiological phenomenon known as the alternation of generations, which Chamisso had first indicated in the Salpæ. His last publication, "Mémoire pour servir à la connaissance des Crinoïdes vivants," caused especial interest, by showing that a race of animals, supposed to be extinct for a period so long as only to be measured by the duration of several past geological epochs, occurred in a living state in the abysses of the Norwegian seas. This discovery mainly induced the recent exploration of our own seas at great depths, which has produced such wonderful results; and the living Crinoid, or "stone-lily" (Rhizocrinus Lofotensis), has now been ascertained to inhabit many parts of the Atlantic from the Loffoden Isles to the Gulf of Mexico. The published works of Sars are seventyfour, and they are not less sound and valuable than numerous. One of his sons, Dr. George Ossian Sars, inherits the zoological inclinations and talent of the late Professor, and is second to none in the knowledge of the Sessile-eyed Crustacea.

It is exceedingly to be regretted that, in spite of the most rigid economy, the large family of Professor Sars is. left in very impoverished circumstances, six of his children being wholly unprovided for. May I hope that naturalists and lovers of science will assist me in making a subscription for the temporary relief of this distressed family, and that they will by such tribute to his memory express their admiration of his career and services? I shall be very glad to receive any contributions.

\section{J. GWYN JEFFreys}

\section{LETTERS TO THE EDITOR}

[The Editor does not hold himself responsible for opinions expressed by his Correspondents. No notice is taken of anonymous communications.]

\section{Cuckows' Eggs}

I AM very grateful to Mr. Sterland for asking for further information "on some points of difficulty" in my recent paper on Cuckows' Eggs, because it shows me where I have failed in making myself plainly understood. In endeavouring to reply so far as lies in me to his questions, I will take them in order.

I. "Are they [Cuckows' Eggs] so variable as some assert?"

Mr. Sterland supports the doubt here indicated by the statement of "one of the most eminent and experienced of living oologists:" but who this vologist may be he leaves to be guessed, and I venture with all respect to remark, that quoting an anonymous authority in natural history is quoting no authority at all. I am therefore not willing to bring such experience as I myself have had into conflict with that of this eminent but nameless person. Still, as Mr. Sterland is not satisfied with the opinion on this 